\title{
1. Space exists to stop everything happening in Cambridge
}

It has been said that time is a device to stop everything happening at once to which Dr Dharma Kumar quipped that space was a device to stop everything happening in Cambridge.

Geoffrey C. Harcourt (1969)

Cambridge is one of the most prestigious universities in the world. Its Faculty of Economics embraced Alfred Marshall, Arthur Pigou and John Maynard Keynes. Until the 1980s it was a remarkable outpost for innovative heterodox economics, with leading figures including Nicholas Kaldor, Joan Robinson and Piero Sraffa. Subsequently it became a mainstream department. This chapter considers the intellectual and cultural environment of the Cambridge Economics Faculty, particularly from the 1930s to the 1980s. Post-Keynesian economics and modern heterodox economics sprang largely from this milieu, and they still bear signs of their Cambridge legacy. ${ }^{1}$

I do not believe that the inadequate global headway made by heterodoxy in Cambridge or elsewhere in the last fifty years can be pinned on the insufficiency of its highest achievements. Many setbacks are due to hostility from orthodoxy. But heterodoxy must bear some responsibility. Its fate is partly to do with its practices and its ideological sub-texts, and its persistent avoidance of some major questions.

Science is a dynamic social system that is embedded in shared habits and institutions. We should consider the institutional contexts in which

1 By contrast, the evolutionary economics of Nelson and Winter (1982) emerged in the US. This 'separate heterodoxy' is considered in Chapter 4 below. In addition, a radical economics - composed of Marxists and other socialists - took off in the US in the 1960s (Canterbery, 2010, ch. 5). The French régulation school emerged in the 1970s as an important heterodox stream (Boyer and Mistral, 1978; Aglietta, 1979; Orléan, 1994; Jessop, 1997a, 1997b, 2001). For more on the Cambridge institutional environment see Winch (1969), Johnson and Johnson (1978), Robinson (1978), Tribe (2000) and Neild (2012). Thirlwall (1987, 2015), Marcuzzo et al. (1996), Pasinetti (2007), Harcourt and Kerr (2009), King (2009), Martins (2014) and others provide accounts of the ideas of leading Cambridge economists. 
science is fostered and passed on. This chapter is more a history of institutions and practices than it is a history of economic thought. It addresses the institutional settings in which post-Keynesian and heterodox economics were nurtured in Cambridge, before heterodoxy lost control of that citadel in the 1980s. Ideas are vital, but institutions are their vehicles and their enablers.

Influence within a scientific discipline depends on engagement with others, especially with those who hold sway within academic systems of authority and prestige. Cold logic is important, but not enough. The success or failure of a school of thought is governed by more than the persuasiveness or weaknesses of its ideas. Groups of researchers make headway through conversations with prestigious communities with shared concerns. It is important to address the prevailing agenda in those communities, especially if it is hoped to change it. Avoidance of pressing issues can be damaging. Shortcomings are often errors of omission, and not merely errors of commission. It is shown in this chapter that there were some characteristic lacunae in the Cambridge heterodox agenda.

Science advances through critical scrutiny and dialogue with experts in the same field. Hence science requires concentrations of specialists who intensively interact with one another, to correct errors, to pose alternative hypotheses, to check results, and to draw attention to related work in the area. If someone was to design the institutional structure of a modern university that maximized such interactions, then it would look very different from the rambling, byzantine structures of Cambridge or Oxford. Yet despite their arcane and time-consuming organization, these ancient universities prospered because of their prestige and their ability to attract great talent.

Before 1960, university education in Britain was the privilege of a male-dominated group of less than 4 per cent of the adult population. In 1945, Britain emerged victorious, but battered and impoverished, from a devastating world war. Resources for research and university appointments were highly limited. All located in London or within its commuter belt, three elite universities dominated research in economics. As the historian of economics Roger Backhouse (1996, p. 35) wrote:

In 1945, British economics was dominated by three institutions: Oxford, Cambridge, and the London School of Economics (LSE). There were other institutions, but they were small in size and provincial in more than the geographical sense. Of these LSE was perhaps the most open to international influences ... contrasting strongly with the Cambridge habit of focusing mainly on work by other Cambridge economists. 
Of the three, economics at Cambridge was globally the most prestigious, largely because of the enduring influence of Marshall, Pigou and Keynes. By 1945, the global stature of Keynes was enough to make Cambridge pre-eminent.

The Canadian economist Harry Johnson read economics at Cambridge from 1945 to 1946 . He was a lecturer there from 1949 to 1956 . He noted a prevailing attitude where 'only a small number of ... economists, almost exclusively in Cambridge, Oxford, and London, [were] considered as worthy of attention or criticism' (Johnson and Johnson, 1978, p. 98).

But the number of economists in Cambridge before and immediately after the Second World War was tiny, consisting of about seven active university lecturers and 'half a dozen fellows scattered around the various colleges' (Robinson, 1978; Durbin, 1985, p. 104).

The modern research university was much more developed in the US than in the UK. At least until the 1970s, relatively few lecturers or professors in economics in the UK had PhDs (Simpson, 1983, 2009). Even at Oxford and Cambridge, college-based institutional structures ensured that priority was often given to undergraduate teaching, rather than to postgraduate studies and research.

After a brief further discussion of the Cambridge context, this chapter touches on the Cambridge debates on capital theory, the relative neglect of individual motivation and microeconomics by Cambridge heterodoxy, some ramifications of Joan Robinson's socialism, and the general Cambridge neglect of the socialist calculation debate. The chapter finishes on the battles between 'left' and 'right' in the Faculty of Economics and Politics and on the active promotion of Cambridge heterodox ideas in North America and elsewhere. ${ }^{2}$

The avoidance of some key microeconomic issues, the neglect of the socialist calculation debate and the tendency to assume that neoclassical theory is generally pro-market are all unfortunate features that persist to this day in the global networks of post-Keynesian and heterodox economics that were largely spawned by Cambridge from the 1960s onwards. The global evolution of heterodox economics has been highly path dependent.

2 When I was at Cambridge in 1992-98, the term 'left-wing economics' was often used by its proponents. It was also used in radical circles of economists in the US (Canterbery, 2010, ch. 5). 


\section{THE CAMBRIDGE CRUCIBLE}

The importance of a scientific community, combining a degree of competition with norms of cooperation, was underlined by the sociologist Robert Merton (1942), and by philosophers of science Michael Polanyi (1962), Thomas Kuhn (1970), David Hull (1988) and Philip Kitcher (1993). Johnson regarded Cambridge as inadequate in these respects, and he explained this weakness largely in terms of the pre-eminence of the colleges (Johnson and Johnson, 1978).

The Oxbridge universities and their associated colleges are all separate legal entities, although they are tied together by numerous customs and contractual obligations. Their legal separability means that it is possible (at least in principle) to be employed by the university and not by a college, by the college and not by the university, or by a college and the university. (There are some differences between Oxford and Cambridge in this area, but they need not concern us here.) Keynes, for example, was primarily a fellow of King's College. He never became a professor at the university. Furthermore, while the universities have been under-financed, some of the older Oxbridge colleges were, and still are, among the richest property owners in the UK.

Dominated historically by teaching and accommodation requirements for residential undergraduates, the legally autonomous Oxbridge colleges were less well suited for research and for postgraduate education. ${ }^{3}$ Oxbridge college fellows were given 'heavy burdens of elementary teaching in which they had to cover the entire range of economics' but 'were under little pressure to publish' (Backhouse, 1996, pp. 34-5). As Robert Locke (1988, p. 99) pointed out: 'isolating ... students and tutors in colleges ... denied them the specialised instruction taught by acknowledged experts in specific fields of economics, which is the hallmark of American undergraduate and graduate education.'

Yet there were compensating mechanisms. Oxford and Cambridge recruited from the upper echelons. Although the ancient college system was ill-suited to the formation of dense networks of specialist university researchers, Oxbridge provided links with elites outside the university, including opportunities for some to advise business or government.

In this manner, Keynes was able to use his connections and engage with a wider community of intellectuals and policymakers. His father was an accomplished economist and administrator at Cambridge. Like

3 In the 1960s, two colleges (Clare Hall and Darwin) were set up exclusively for postgraduates. The remaining 29 Cambridge colleges have a large undergraduate intake. 
several prime ministers, and numerous members of the British Establishment, John Maynard attended Eton Public School. As a student at Cambridge he was taught by Marshall. From 1913 onwards, he advised governments and participated in Royal Commissions. In 1915 he took a position at the UK Treasury, representing it at the 1919 Versailles Peace Conference. In 1931 he visited the US, at the invitation of the University of Chicago. Visits to the US followed in 1934 and several times in the 1940s. His economics benefited from rich practical experience and his prestigious Anglo-American connections.

Academic networks were then almost entirely male. Born twenty years after Keynes, Joan Robinson was from an upper-middle-class background. She studied economics at Girton College in Cambridge, and came under the influence of Maurice Dobb, who was a member of the Communist Party and a gifted Marxist academic. She graduated in 1925. In the 1930s she was engaged in intensive debates surrounding Keynes's research. In 1933 she published her milestone work on The Economics of Imperfect Competition. But it was not until 1937 that she obtained a university lectureship at Cambridge. Despite her influence and prodigious output, it was not until 1965 that she obtained a full professorship at her university.

As Geoffrey Harcourt and Prue Kerr (2009, pp. 8-9) have noted, Robinson suffered from prejudice against her gender, including from at least one leading economist who believed that women were incapable of abstract economic theory. But Robinson declared in later life that if she had suffered discrimination it was because of her ideas, not because she was a woman (Golden, 1976). She had a dogged personal determination and a sincere concern about the injustices of the world.

Keynes's connections with political life were mainly through Establishment networks. He was a supporter of the Liberal Party. By contrast, Robinson was a fervent socialist, closely connected with Marxist economists such as Dobb at Cambridge, and with the Polish Marxist Michał Kalecki, whom she befriended in 1936. Kalecki became a major influence on Robinson's thinking and he was placed alongside Keynes as a pioneer of the Keynesian Revolution. 'Many of her writings in the 1930s and 1940s were directed towards the formation of Labour Party policies in the light of Keynes's and Kalecki's findings' (Harcourt and Kerr, 2009, p. 10). But while she was influenced by Marxism, she did not swallow Marx whole. She rejected Marx's labour theory of value and his theory of the tendency of the rate of profit to fall (Robinson, 1942). She criticized those who parroted Marx uncritically.

Piero Sraffa was another major figure in Cambridge economics. Born in Turin in Italy, he had been active there in socialist politics, and thereby 
he had become a close friend of the famous Marxist Antonio Gramsci. In a seminal article, Sraffa (1926) exposed serious problems in Marshallian analysis. Sraffa came to Cambridge as a lecturer in 1927 and was elected to a fellowship at Trinity College in 1939. Although it is less than 100 pages, his most famous work entitled Production of Commodities by Means of Commodities (Sraffa, 1960) took decades to complete. Sraffa built on the classical approaches of David Ricardo and Karl Marx, particularly from the reproduction schemes in the second volume of Capital (Marx, 1978).

Its logic is brilliant, but the work is idiosyncratic in its notation and style. A modicum of cooperation by its author with someone versed in matrix algebra could have sorted out the notational oddities and aided further mathematical development. ${ }^{4}$ His work has been interpreted not only as a 'prelude' to a critique of mainstream theory, but also as an opening fanfare for a modernized revival of Marxist economics (Meek, 1961; Dobb, 1970; Eatwell and Panico, 1987; Hollander, 2000; Sinha, 2016).

\section{SRAFFIAN ANALYSIS AND DEBATES OVER CAPITAL THEORY}

Robinson (1953) triggered the famous Cambridge controversy in capital theory by asking how capital was measured. By capital she generally meant capital goods. The latter are clearly heterogeneous, and any single scalar measure of an aggregation required a set of weights or values to quantify them as an aggregate. Sraffa (1960) showed that relevant economic measures of such aggregates of physically heterogeneous items were not independent of prices or of the distribution of income between wages and profits.

Sraffa's arguments developed into a concerted attack on the neoclassical aggregate production function. Production functions serve several purposes in mainstream economics. In neoclassical theory, wages and profits are related to the marginal revenue products of labour and capital respectively. Going further, John Bates Clark (1899) and others suggested that the aggregate production function upheld a normative justification of the appropriation of profits by capitalists. These distributive shares of labour and capital were controlled by a 'natural law'.

4 See Steedman (1977) and Schefold (1989), for example. 
Hence production functions were used in attempts to explain or justify the distribution of income between rival social classes under capitalism.

This pro-capitalist political conclusion energized the Cambridge economists to attack the aggregate production function. But they treated it largely as a technical problem. In 1961, Robinson visited the Massachusetts Institute of Technology (located in Cambridge in the US) with Pierangelo Garegnani from Italy. They argued with Samuelson over the aggregate production function. Their debate focused on the possibilities of capital reversing and of capital reswitching. Capital reversing means that, contrary to many neoclassical textbooks, a less capital-intensive production technique may be associated with a lower value of the rate of profits. Reswitching means that the same technique, having been the most profitable for a range of profit rates and wage rates, could also be the most profitable at another range of profit rates and wage rates, even though different techniques were the most profitable at intermediate values. If such things could happen, then the standard, 'well-behaved' aggregate production function would be undermined.

In response, Samuelson (1962) tried to rescue orthodoxy with the 'surrogate production function'. But within four years, Samuelson (1966) admitted that capital reversing and capital reswitching were possible. In a powerful technical paper, Garegnani (1970) triumphantly demonstrated that with heterogeneous capital goods, aggregate production functions could take a variety of exotic and 'badly-behaved' forms. Samuelson (1962) had been decisively refuted.

The Cambridge UK side of the debate were triumphant. They believed that they had struck a major blow against neoclassical economics and its use to bolster the ideology of capitalism. Incidentally, the timing of the final theoretical battle, from 1962 to 1970 , coincided with a huge global upsurge of popular protest, particularly against the Vietnam War but also against capitalism. In his definitive account of the capital controversy, Harcourt (1972, p. 13) saw a correlation between analytic views on economic theory and normative stances on capitalism and the Vietnam War:

[If] one were to be told whether an economist was fundamentally sympathetic or hostile to basic capitalist institutions, especially private property and the related rights to income streams, or whether he were a hawk or a dove in his views of the Vietnam War, one could predict with a considerable degree of accuracy both his general approach to economic theory and which side he would be on in the present [capital theory] controversies. 
But Harcourt failed to identify any causal mechanism that might explain this apparent correlation. Why did two sides in an argument over capital theory correlate with different ideological positions on capitalism or the Vietnam War? There is no logical connection between these stances.

But there is a possible causal explanation for the correlation. Critics of neoclassical capital theory saw their arguments as an assault on a theoretical justification for a capitalist economy based on wages and profits. Their critique drew support from their anti-capitalist ideology. Ideological opposition to capitalism also fuelled opposition to its wars against Communist regimes. Leftist ideology thus explains the adoption of the Sraffian critique plus the rejection of capitalism and its wars against Communism. On the other side, status quo attitudes to politics are often linked to status quo attitudes to economics. Hence the correlation between stances on the Vietnam War and positions on the capital controversy are explained by political ideology, rather than by economic analysis. Ideology motivated the different positions.

Cambridge heterodoxy neglected other criticisms of the neoclassical theory of distribution. As an exception, sometime after 1970, Robinson (1979, pp. 37-40, 94-5, 116) acknowledged Thorstein Veblen's (1908) criticism of Clark (Cohen, 2014). Robinson was especially impressed by Veblen's observation that economists had habitually conflated the notions of capital-as-finance and capital goods. Veblen had also emphasized the relative economic importance of knowledge, held within a community. He pointed out that if physical capital was destroyed, then possession of appropriate knowledge could restore the production technology. But if the necessary knowledge and skills were lost, then any surviving capital goods would be unusable. He also stressed the financial and creditrelated aspects of capital, and their dependence on historically-specific social institutions. But while praising Veblen, Robinson made little of these insights in her own analysis. She carried on treating capital as physical stuff.

Robinson and her co-workers overlooked other important, nonmathematical criticisms of Clark's position, including by the liberal economist John Atkinson Hobson. Hobson (1900) noted that with production functions, all (positive) factor inputs help to determine the output. In marginal analysis, other factors are held constant as one factor varies. But with positive values throughout, the variable factor still acts in combination with flows of the other factors. Contrary to Hobson's critics, this did not amount to a confusion of total with marginal productivity. Hobson simply pointed out that a marginal output is not produced by the varying factor alone. Identifying the marginal effect of a variation in the services of one factor cannot suppress the causal impact of the other 
factors on output, even though their rate of flow is held constant. All the inputs act causally at every point: they are interdependent. Consequently, one cannot conclude that shares of output are attributable to separate factors.

Yet leading economists make this mistake. For example, in a text on price theory, Milton Friedman (1962, p. 198) relayed the idea that 'marginal productivity theory shows that each man gets what he produces' (as long as there is sufficient market competition). He did not consider that the notion of one factor 'getting what it produces' is problematic. Production functions involve a combination of capital goods and labour as joint and interdependent inputs. Hence the very notion on one factor 'getting what it produces' is mistaken, even within the assumed terms of a standard production function. Furthermore, because of this interdependence of factors, justifications in Lockean terms of property rights over outputs fail: all input facts are 'mixed' with the output. Clark's normative theory thus collapses, even if his production function survives. ${ }^{5}$

But defeating an important argument that was used to defend capitalism does not mean that capitalism is indefensible. To attack capitalism effectively one must critique the core notion of a market system driven by profit and propose a feasible and superior alternative. To his credit, Harcourt (1972, p. 91) also argued that economists ought to be asking whether profits are justified, and not simply how profits are determined. But few among the Cambridge left economists pursued this philosophical question. It was as if the objections to a system based on profits were obvious, and socialism was an unassailable solution to replace capitalism and its defects. They lived and worked in a prestigious leftist bubble where such 'obvious' claims often went unchallenged.

While Marx's Capital and Keynes's General Theory explicitly engage with empirical reality, Sraffa's book does not, despite its Marxist allusions. As Mark Blaug (1974, p. 28) put it: 'there is hardly a sentence in the book which refers to the real world and it is perfectly obvious that Sraffa is only too keen to exchange practical relevance for logical rigour.' Blaug (1990, pp. 225-6) later commentated: 'it is time to ask whether it is something about the very nature of Sraffa's approach that has so far made it totally irrelevant to practical issues.'

5 See Pullen (2010) for an excellent discussion. Note also that, for the sum of marginal productivity allocations to correspond to total output, the production function must be assumed to be linearly homogeneous, which Edgeworth (1904) among others doubted were true in reality. 
Blaug (1974, 1990) compared Sraffian economics with neoclassical general equilibrium theory. Although the Sraffian system is static, it does not mention equilibria or equilibration mechanisms, and it may thus plead that it is not an equilibrium theory (Sinha, 2016). But both are fact-lite approaches, suspended in mid-air from inflated abstract assumptions, generating internal puzzles rather than engaging with empirical reality.

The neoclassical citadels were largely unshaken by the Cambridge theoretical assault (Cohen and Harcourt, 2003). Sraffa's Production of Commodities received a flurry of citations in the literature but afterwards its impact declined (Hodgson, 1997). The Sraffian results rest on the assumption of heterogeneous capital goods and point to the problem of valuing them in the aggregate. Disaggregated versions of neoclassical theory - particularly of general equilibrium theory - did not face this problem. As Blaug (1974, p. 9) pointed out: 'so long as we stay firmly within the microeconomic tradition of Walrasian general equilibrium theory, we avoid every one of the endlessly reiterated dilemmas of the Cambridge critics'. Similarly, Frank Hahn (1975, p. 362) argued that 'there is not a single formal proposition in Sraffa's book which is not also true in a General Equilibrium model constructed on his assumptions.' Furthermore, against 'the followers of Sraffa', Hahn (1982, p. 353) concluded that 'there is no correct neo-Ricardian proposition which is not contained in the set of propositions which can be generated by orthodoxy' in a disaggregated general equilibrium analysis. Hence 'the neoRicardian attack via logic is easily beaten off.' Hahn's 1982 article was published in the heterodox Cambridge Journal of Economics, with the aim of reviving a debate that orthodoxy had mostly ignored. But no defence of the Sraffian approach appeared in response to Hahn in the journal. 6

This does not imply that general equilibrium theory is a viable way forward. Blaug $(1992,1997,1999)$ repeatedly emphasized that the development of general equilibrium theory after the Second World War, which displaced the previous Marshallian dominance, had driven economics in an unhelpful direction, leading to an obsession with formalized, technical problems and a disengagement from empirical reality. Although Hahn had been a major contributor to the development of general equilibrium theory (Arrow and Hahn, 1971), he fully understood that its research programme had been derailed in the 1970s. Theoretical results showed that 'well-behaved' aggregate demand functions could not

6 Much later, Sinha (2016) claimed to rebut Hahn (1982). 
be guaranteed in a disaggregated general equilibrium framework. The supreme quest for secure micro-foundations had failed (Hahn, 1975; Kirman, 1989; Rizvi, 1994a).

Hahn was a university lecturer at Cambridge from 1960 to 1967. He returned in 1972 to take up a full professorship. His criticism of Sraffian economics was enough for him to be labelled on the 'right' of the Cambridge Faculty. This was an absurd political appellation. Hahn was a social democrat. He opposed unlimited markets and campaigned against the policies of Prime Minister Margaret Thatcher. Kenneth Arrow, who was Hahn's co-author of their 1971 text on general equilibrium theory, was a strong socialist. Once again, Hahn's 'left' opponents at Cambridge seemed enduringly unaware that general equilibrium theory had been used in the 1930s in attempts to show, against Hayek and Mises, that socialism was possible. Hahn himself used general equilibrium theory to argue that the necessary conditions for a competitive general market equilibrium were so difficult to satisfy in reality that consequently there is an important economic role for the state.

While the Sraffian critique on the aggregate production function was important and logically robust, much of the remaining neoclassical apparatus was untouched by the Cambridge attack. In fact, Sraffian analysis had much in common with orthodoxy. Blaug (1974, p. 3) put it forcefully: 'If there is something wrong with neo-classical economics as there may well be - the Cambridge theories share all of its weaknesses and practically none of its strengths.' Both types of analysis are largely static. Key problems of information, knowledge and uncertainty are underestimated in both Sraffian and neoclassical models.

The foundational use of purely physical inputs and outputs in the Sraffa system neglects questions of learning and knowledge which had been given inadequate attention by orthodoxy and heterodoxy alike. This was the nub of Veblen's (1908) astute attack on the neoclassical concept of capital. Knowledge and learning are dynamic and relate uneasily to the fixed physical coefficients and other static assumptions of the Sraffa system. Knowledge and learning are difficult to reconcile with maximizing agents, unless learning is treated unrealistically as asymptotic to some final equilibrium outcome.

The Sraffian critique leaves the maximizing, equilibrium-oriented core of neoclassical theory intact. It does not entail an alternative theory of human agency and interaction. It assumes that the long-period positions will somehow reflect and affect the expectations and actions of agents, without explaining how the average rate of profits and prices are attained. Whether conceived as an internal critique of neoclassical theory, or the foundation of an alternative paradigm for economics, Sraffian economics 
has no theory of individual human action and no account of the actions of agents, their interactions and their consequences.

These lacunae weakened the Sraffian approach in a crucial theoretical area. Neoclassical economics always emphasized individual incentives. But it took a questionable view of what those incentives mean and how they could be modelled: it assumed self-interest and utility maximization. Any successful assault on the neoclassical citadel would have to criticize these assumptions carefully, and not simply dismiss them with vague labels such as 'marginalism' or 'methodological individualism'. A superior theory of human motivation and interaction was required. Sraffian economics did not provide one. ${ }^{7}$

Unlike some other aspects of Cambridge economics - particularly the empirically oriented work of Kaldor (1966, 1972, 1975a, 1975b) Sraffa's economics makes few testable claims. It does not challenge neoclassical economics by proposing a novel and superior explanation of accepted facts. Like neoclassical general equilibrium theory, it does not engage with the real world. Both are self-contained logical exercises, generating their own internal technical challenges to keep their adherents intellectually occupied. ${ }^{8}$

7 In the following chapter and in Hodgson (2007) I show that methodological individualism is an ambiguous term. There is no consensus on its meaning. See also Arrow (1994).

8 I add a personal recollection here. Enthralled by Cambridge ideas in the 1970s, I noticed that money was central to the analyses of Marx and Keynes - albeit in different ways - but it was entirely missing from Sraffa's Production of Commodities. If there were to be any synthesis between Sraffa and Keynes - as Robinson, Eatwell and others proposed - it seemed vital to span this gap. I sent a draft paper on 'Money and the Sraffa System' to Robinson in 1974. She generously responded, and we corresponded for a while. The crux for her was expressed in a letter to me of December that year: 'Money is a social convention not a physical product' but by contrast 'Sraffa's model is for industrial production' (Robinson 1974, her emphasis). She was of course right about money, especially when it is not a produced commodity of intrinsic value, such as gold. But production too involves social conventions and institutions, and not merely physical stuff. Sraffa's model also involves prices, wages and profits, which in the real world are also related to money. It seemed to me that Robinson was adopting a version of the pre-Keynesian classical dichotomy, where physical assets were placed on one side of an analytical divide, with money on the other. In any case, it still perplexed me how Sraffa, Marx and Keynes could be reconciled. I tried to press the point, but eventually she passed our correspondence to Eatwell, which came to nothing. Some years later I published a revised version of the paper, and this work became part of a wider book on the topic (Hodgson, 1981, 1982). But soon afterwards I realized that a coherent synthesis between Keynes and Sraffa is impossible because of their fundamentally different ontological and other assumptions. Capitalist production is about institutions, albeit played out in a material world. So I turned to American institutionalism - particularly Veblen - instead (Hodgson, 1988). 


\section{INDIVIDUAL MOTIVATION AND MICROECONOMICS}

Cambridge economics as a whole lacked an alternative theory of motivation and interaction. Little work was done on an alternative, psychologically grounded theory. Critiques of utility maximization were often brief. For example, in her Economic Philosophy Robinson (1964a, p. 48) attacked the core neoclassical concept of utility: 'Utility is a metaphysical concept of impregnable circularity; utility is the quality in commodities that makes individuals want to buy them, and the fact that individuals want to buy them shows that they have utility.'

A good point, nicely phrased. But Robinson seemed to think that finished the matter. Although circularity and unfalsifiability are important and consequential limitations, effective critique of utility maximization cannot rely on these alone. ${ }^{9}$ Beyond occasional remarks such as this, Robinson devoted little attention to the critique and replacement of the assumption of utility maximization. In her high-profile attempt to outline the priorities for economic theory in her article on 'What are the questions?' in the prestigious Journal of Economic Literature, the topic of utility maximization and its possible replacement does not appear (Robinson, 1977b).

If utility is to be rejected, then an alternative theory of individual motivation is needed. One possible port of call would have been the instinct-habit psychology adopted by Veblen (1914). But the influence of American institutionalism on Cambridge economics was minimal. ${ }^{10}$

An obvious place to look for insights on human cognition and motivation would have been the behavioural economics of Herbert Simon (1947, 1955, 1956, 1957, 1979). Simon drew from psychology and he researched cognitive processes and organizational behaviour. He was

9 Note how Robinson used 'metaphysical' as a negative word, in accord with Comtean positivism. Similarly, Robinson and Eatwell (1973, pp. 3, 9-10, 29, 36, 42, 149, 171) repeatedly dismissed 'metaphysical' propositions in their textbook. But Willard van Orman Quine (1953) had already showed that even positivism and empiricism depended on metaphysical assumptions. Since then it has become generally accepted in the philosophy of science - as Veblen understood long ago (Veblen, 1900; Camic and Hodgson, 2011, pp. 12-13; Hodgson, 2004a, pp. 147-8, 215) - that some unfalsifiable and unprovable 'metaphysical' propositions are essential for science to operate. These include the assumption of causality and the principle of the uniformity of nature.

10 Another problem was that the psychological aspects of Veblen's thinking had been largely abandoned by later American institutionalists (Hodgson, 2004a). Nevertheless, American institutionalism had some influence on the Keynesian revolution and Keynes briefly corresponded with Commons. In addition, Robinson (1964a, pp. 103-10) cited Clarence Ayres (1944), and there was an indirect link through Allyn Young and Gunnar Myrdal to Kaldor (Hodgson, 2004a, pp. 152-3, 285, 309-315). 
influenced by the American institutional economist John R. Commons, among others (Simon, 1979, p. 499). But Simon's work was generally ignored by leading Cambridge economists. I have found no mention of Simon in the published works of Kaldor, Robinson or Sraffa.

Or the Cambridge critics could have looked closer to home. They could have taken their cue from Marshall. He had a notion of human motivation that was superior to the mechanical 'pleasure machines' of much neoclassical theory. Marshall (1920, p. vi) insisted in his Principles that 'ethical forces are among those of which the economist has to take account.' He was sceptical of attempts 'to construct an abstract science with regard to the actions of an "economic man," who is under no ethical influences and who pursues pecuniary gain warily and energetically, but mechanically and selfishly.' Cantabrigian heterodoxy made little attempt to build on this Marshallian legacy.

Robinson briefly mentioned morality in a few places (for example Robinson, 1969a, pp. 33-4; Robinson and Eatwell, 1973, p. 271). But she never articulated a theory of moral motivation. She wrote nothing about moral sentiments and their emotional grounding. She treated morality as a normative yardstick of behaviour, to be fulfilled when capitalism has been replaced by socialism. Hence Robinson (1973, pp. 4, 13, 37; 1977a) disliked markets because she believed they promoted a selfish morality. She also rejected 'market socialism', partly because of 'the erosion of socialist morality that monetary incentives bring about'. Robinson saw morality as vital for a planned socialist economy, where hard work and loyalty would be energized through moral propaganda.

There was inadequate recognition that capitalism too relies on moral values (Schumpeter, 1942). Indeed, no society is possible without moral bonds and widespread sympathy for others (Smith, 1759). And contrary to what Robinson suggested, markets do not always lead to selfishness. Markets enable wider interpersonal interactions and can help to promote mutual understanding and trust. Consideration of morality does not necessarily mean the abolition of capitalism. ${ }^{11}$

Although she paid notable attention to prices and imperfect competition, other vital microeconomic issues were neglected in Robinson's work. For example, Marshall (1920, pp. 138-9) had insisted on the importance of knowledge and organization: 'Knowledge is our most powerful engine of production ... Organization aids knowledge; it has many forms ... it seems best sometimes to reckon organization apart as a

11 See Hirschman's (1982) brilliantly nuanced analysis of markets, and the evidence in Henrich et al. $(2001,2004)$ that involvement in markets does not generally increase selfish behaviour. 
distinct agent of production.' Redolent of Veblen and consonant with Simon, this Marshallian emphasis on knowledge and organization had surprisingly little impact on Cantabrigian heterodoxy.

Even Kaldor treated knowledge too casually. For example, Kaldor (1966, p. 13) proposed that different plants in a multinational corporation 'must have had the same access to improvements in knowledge and know-how'. This ignored the importance and ubiquity of 'unteachable' (Penrose, 1959) or 'tacit' knowledge (Polanyi, 1958, 1967), which we know but cannot readily explain. For example, we follow the rules of our native language, while being unable to make many of them explicit. Tacit knowledge cannot easily be transferred from individual to individual, or from production plant to production plant, even if copyright or other legal impediments are lacking.

Research opportunities in key areas were missed. The young Sen wished to research social choice and welfare theory for his $\mathrm{PhD}$. He attempted to find a supervisor in Cambridge. He could not find anyone at Trinity - his own college - or in the university as a whole. Sen (1999) wrote: 'I had to choose quite a different subject for my research thesis ... The thesis was on "the choice of techniques," which interested Joan Robinson as well as Maurice Dobb'.

Sen received his $\mathrm{PhD}$ in 1959. But he was soon to make major contributions to his preferred topic of social choice theory (Sen, 1970). Sen $(1973,1977)$ then published some of the best-ever critiques of the rational, utility-maximizing individual. Sen (1979, 1981, 1985a, 1987a, 1987b) went on to make a number of additional major contributions in the areas of welfare economics, human motivation and identity, as well as to develop his analysis of famines, which earned him the Nobel Prize in 1998. Sen's earlier work from Cambridge on the choice of techniques has received much less attention.

Peter Earl studied at Cambridge from 1974 to 1979. He became interested in Simon's behavioural economics. He was advised that his prospects for a position in Cambridge 'were not very good since [his] enthusiasm for behavioural economics would mean that [he] would be rejected by both the neoclassical economists and those on the left' (Earl, 2018). Earl also became interested in the work of George L.S. Shackle (1955, 1972, 1974). Shackle gave even more prominence to Keynes's concept of uncertainty than several other post-Keynesians and he emphasized the role of imagination and 'potential surprise'.

More complex theories of human motivation do not necessarily lead to socialist policy conclusions. Much of the emphasis on morality and duty, for example, is found in conservative as well as radical strands of thought. Generally, understanding humans as more complex creatures, 
with finite cognitive and computational capacities, may help us understand some limitations of the market mechanism, but it does not necessarily steer us toward socialism. Perhaps the politically ambivalent or uncertain outcomes of these ideas were part of the reason for neglect by leftist heterodox economists?

Largely, with some exceptions, the Cambridge left economists gave precedence to macroeconomic over microeconomic theory. Excursions into micro were often concerned with price theory or imperfect competition, and only rarely with the psychological or other grounding of human motivation. ${ }^{12}$ From 1968 to 1970, Jan Kregel was a research student at Cambridge, under the supervision of Robinson and Kaldor. Subsequently, Kregel (1973, p. 203) wrote: 'The micro-analysis of the macro theory remains one of the least refined areas of post-Keynesian theory.' This precedence toward macro- over micro- was also obvious in the long-awaited but short-lived Cambridge textbook authored by Robinson and John Eatwell (1973). Blaug (1974, pp. 69, 71-2) commented:

Joan Robinson's much-awaited textbook in 'modern economics' perfectly exemplifies the typical attitude of Cambridge economists to micro-economics. The whole of traditional price theory is covered in one chapter ... [some] prices are formed by conventional mark-ups on prime costs, the level of the mark-up itself being left unexplained. Apart from this chapter, the book is doggedly macro-economic in treatment ... A striking omission from the book is any mention of the closely related concepts of externalities and public goods, which most economists would nowadays regard as the basic ingredients of 'market failure' that has come to be fruitfully applied ... to problems of pollution and congestion.

The neglected concepts of externality, market failure and social cost were used by Pigou (1920) and others to identify the limits to the general use of the market mechanism. Pigou's analysis was traditionally part of the theory of a mixed economy, to which Samuelson (1954) and Galbraith (1958) added the concept of public goods. Were these areas of analysis neglected in the textbook because they suggested a mixed economy involving markets, rather than wholesale socialist planning? ${ }^{13}$

12 An exception is Steedman's (1980) powerful but neglected paper on nonautonomous preferences. Steedman studied at Cambridge. Hollis and Nell (1975) also criticized core neoclassical assumptions.

13 Robinson and Eatwell (1973, pp. 309-310) briefly dismissed Pigou's analysis, without explicit mention of the concepts of externality or market failure. Robinson and Eatwell (1973, p. 47) caricatured his position as one where 'Pigou described a number of cases in which laissez-faire is not necessarily beneficial, but he treated them as exceptions to a rule which, in general, could not be questioned.' In fact, Pigou took a pragmatic and 
Not only were Pigou and Samuelson given short shrift in the Robinson-Eatwell textbook, but also their critics were ignored. Approaches to externalities and public goods came under attack from the Chicago school, following Ronald Coase's (1960) classic article. But the textbook gives its student readers no guidance on how to deal with the rising pro-market reaction to the 'market failure' analyses of Pigou, Samuelson and others. Robinson and Eatwell even neglected the alternative theory of social cost developed by K. William Kapp (1950), which was influenced by Pigou and reached conclusions that were more aligned with their left politics. ${ }^{14}$

From the 1950s to the 1980s the Cambridge department was relatively pluralistic, with a variety of different viewpoints. But there was more pluralism in some areas than others. We have noted the lack of opportunities for scholars like Sen and Earl to research on particular microeconomic issues. Pluralism without an adequate consensus on core issues is dysfunctional. There was insufficient agreement on some basic theoretical issues and this absence made dissident economics in Cambridge vulnerable. When their final defeat came, it was relatively swift.

\section{THE POLITICS AND ECONOMICS OF JOAN ROBINSON}

Cambridge was a hotbed of leftist political radicalism and Robinson was the most influential figure within Cambridge heterodox economics. From the 1960s she was to play a central role in the development of post-Keynesian and heterodox economics in the US as well as in Britain.

experimental approach toward the question of socialism versus capitalism. While accepting capitalism 'for the time being', he stressed the importance of 'graduated death duties and graduated income tax ... with the deliberate purpose of diminishing our glaring inequalities of fortune and opportunity which deface our present civilisation.' He also favoured substantial government-promoted investment in 'the health, intelligence and character of the people' (Pigou, 1937, pp. 137-8). Robinson and Eatwell (1973, p. 243 n.) mentioned Samuelson momentarily, in one footnote in the entire textbook, in regard to international trade, but not to his seminal work on public goods. Galbraith gets three mentions, but none is to his classic Affluent Society (Galbraith, 1958) with its famous popularization of Samuelson's (1954) concept.

14 Kapp (2016) focused on the failure of market prices to reflect social costs and individual needs. He seemed to assume, but did not show, that any meaningful calculation of costs or prices was possible in a planned economy. He appraised the limits of markets, but not those of planning. During their correspondence in 1941, the leading American institutional economist J.M. Clark noted this lack of 'balance' in Kapp's analysis (Berger, 2017, pp. 100 ff.). Like Commons, Clark promoted a reformed capitalism. 
Her political standpoint, as well as her economics, influenced these movements. Some consideration of her political views is essential for this narrative.

Political attitudes help to determine what an economist thinks are important for further study, what can be taken as given, and what is ignored. Robinson's political views affected the agenda in terms of economic theory, framed political opinion and recruitment in these dissenting communities, and guided views on the relationship between economic theory and political practice. But one omission stands out as of enduring importance. Robinson simply took the viability of socialism for granted and she failed to discuss the twentieth-century theoretical debate on the economic feasibility of socialism. This omission persisted among the rising post-Keynesian and heterodox movements.

Before and during the Second World War, Robinson produced pamphlets, short pieces, newspaper articles and radio talks on socialist planning (Robinson, 1937, 1943a, 1943b, 1943c, 1943d, 1943e). This material was largely designed for a wider audience. In one place she advocated complete nationalization of the productive sector, because 'a patch of national control here and there cannot make a great improvement on the design' (Robinson, 1943a, p. 19). In her planned economy, as Harcourt and Kerr (2009, p. 66) pointed out: 'She would leave some fringe consumer items in the hands of private production just to provide some choice.' Robinson believed that an entire modern complex economy could be planned from the top.

As Harcourt and Kerr (2009, p. 66) elaborated, she looked, 'uncritically and idealistically, to Russia as an example of successful, rational planning. The Soviet example was an inspiration to the socialists and Joan Robinson defended Stalin into the 1950s and 1960s.' In her review of Dobb's (1949) Soviet Economic Development since 1917, Robinson (1949) was impressed with the 30 years of Soviet progress and saw it as a 'grand moral' for under-developed nations.

Robinson (1965, p. 28) supported the North Korean regime and extolled its 'economic miracle ... All the economic miracles of the post-war world are put in the shade by these achievements.' But the North Korean Seven-Year Plan launched in 1961 turned out to be a massive failure by its own targets: growth slowed dramatically, with relatively little increase in living standards (Chung, 1972). Meanwhile the South Korean economy was beginning to forge ahead. These were serious misjudgements by a prominent economist.

After the Chinese Revolution of 1949, Robinson visited China several times and was a supporter of Mao's policies until his death in 1976. Robinson (1965, p. 193) once wrote that 'no one starved' in the Great 
Leap Forward of 1958-61. In fact, it had led to a catastrophic famine and about 40 million deaths (Dikötter, 2010).

Robinson (1969b, p. 19) also supported Mao's Cultural Revolution and praised Mao's 'moderate and humane' intentions. But after Mao's death 'she discovered, to her horror, that the Chinese had not told the truth even to trusting analysts ... she admitted to having been starry-eyed about the decade of the "Cultural Revolution"" (Harcourt and Kerr, 2009, p. 145). The Cultural Revolution created anarchy for years and led to between half a million and several million deaths - estimates vary widely - due to famine and Red Guard violence (Dikötter, 2016). Robinson had been naïve and deluded by ideology: she had believed the official pronouncements of totalitarian regimes. ${ }^{15}$

The severity of her economic and political misjudgements is rarely noted by her followers. By contrast, links between Chicago economics and the murderous Chilean regime of Augusto Pinochet are often rightly criticized (Valdés, 1995). Pinochet's government killed over 3000 and tortured about 40000 people (BBC News, 2011). But the scale of Robinson's mistake in backing Mao is rarely recognized. Mao's regime led to about 65 million deaths, some millions of which resulted from beatings or torture. This death toll is about 2000 times greater than Pinochet's appalling score. Why is Robinson so rarely criticized for her naïve and irresponsible credulity concerning Mao's monstrous crimes? Perhaps this silence tells us something about the political dispositions of Cantabrigian heterodoxy?

Harcourt and Kerr (2009, p. 58) confirmed that Robinson 'was a Fabian socialist but not a Marxist'. Harcourt and Kerr (2009, p. 74) also admitted that her socialism was 'idealistic and not well-informed by contemporary debates over planning and over the Soviet case.' Blaug (1974, p. 77) was more disparaging: 'A careful perusal of Joan Robinson's voluminous writings ... contributes little of substance to the famous question of capitalism versus socialism.' But the issue of capitalism versus socialism was always prominent in her thinking.

For Robinson, 'Capital accumulation was the key; to overcome "backwardness"' (Harcourt and Kerr, 2009, p. 146) where capital was regarded as physical means of production, and socialism was believed to be the

15 But to be fair, the full scale of suffering under Stalin, Mao and other Communist regimes was not revealed until the 1990s. Courtois et al. (1999) estimated that Stalin's regime in the Soviet Union was responsible for 20 million premature deaths and that Mao's rule in China lead to 65 million premature deaths. Some other estimates are even higher (Rummel, 1994). Tahir et al. (2002) stated that Robinson changed her position in the 1970s, to favour the introduction of market reforms in China. But they gave no clear evidence of this shift in her opinion. 
best arrangement to ensure the rapid accumulation and distribution of this physical stuff. There was little consideration of the institutions, knowledge and incentives that were required to make any system work effectively. ${ }^{16}$

By focusing on the accumulation of capital as physical stuff, Robinson and others neglected the problem of meaningfully evaluating inputs, outputs and processes - otherwise known as the problem for planners of economic calculation. Adequate responses emphasize the price mechanism and an understanding of capital as the money value of investments. This monetary view of capital aligns with what is commonplace in business and accounting, but not in economics. In the monetary view, capital is both the expression, and the instrument for the creation, of money-values, in the historically specific type of economic system known as capitalism. Robinson's largely ahistorical and physicalist view of capital and her failure to appreciate the socialist calculation debate were thus linked.

Other heterodox thinkers exhibited similar limitations. Robinson was not alone. Yet the influence of founders on movements is often greater than that of followers, because organizations and networks congeal and become self-reinforcing as they mature, and it becomes more difficult to change their basic assumptions and their direction.

\section{THE CAMBRIDGE NEGLECT OF THE SOCIALIST CALCULATION DEBATE}

In the 1930s and 1940s most academic economists were at least vaguely aware of the 'socialist calculation debate', which occurred between, on the one hand, the Austrians Friedrich Hayek and Ludwig Mises, and on the other hand, the socialist economists Oskar Lange, Henry Dickinson, Abba Lerner and others. ${ }^{17}$ Because the London School of Economics was

\footnotetext{
16 Robinson's Accumulation of Capital (1969a) is said by some to be her most important work - an attempt to extend Keynes's analysis to the long-run. Capital is never clearly defined in the book, but it is treated as physical stuff throughout. This physicalist conception of capital is commonplace in orthodox economics as well, and criticism is expressed by a tiny minority (Menger, 1888; Mitchell Innes, 1914; Fetter, 1927, 1930; Schumpeter, 1954, pp. 322-3; De Soto, 2000; Piketty, 2014; Hodgson, 2014b, 2015b; Braun, 2015). Physicalist notions of capital are even less-well suited to a modern, knowledge-intensive economy where much production takes the form of services and where information-based, intangible assets are paramount (Pagano, 2014).

17 Hayek (1935), Mises (1920, 1935), Lange (1936-37), Lange and Taylor (1938), Dickinson (1933, 1939), Lerner (1934, 1937, 1938). It was called the socialist calculation debate because at its centre was the problem of calculating meaningful prices in a planned
} 
temporarily moved to Cambridge in the war years, Hayek was no stranger to this ancient university and he interacted with Keynes.

Within his voluminous writings on socialism, Dobb quickly dismissed the arguments of Mises and Hayek against planning (Dobb, 1929, 1937, 1949, 1955, 1960, 1969). Johnson reported that Dobb gave lectures on the 'Economics of Socialism, which was a fairly hot topic in 1945-46 ... they were mostly about the 1930s arguments about socialism, which started with von Mises's assertion that socialism, simply "could not work" (Johnson and Johnson, 1978, p. 129). Dobb attempted to show that Mises was wrong. According to Johnson, Dobb would lecture by reading from his notes in a 'flat monotone'. He would start off with 40 or 50 students and end up with a hard core of Communist Party members and few others. Dobb was active in recruiting students to the Communist Party. Among them was Kim Philby, who became a Soviet spy.

Dobb was not unusual in dismissing the Austrian analysis. The overwhelming verdict among economists by 1945 was that Lange and others had won the socialist calculation debate with sound economic arguments. ${ }^{18}$ It was widely believed that the arguments of Mises and Hayek concerning the unfeasibility of socialism had been answered and refuted by Lange, Dickinson, Lerner and others.

Thus Joseph Schumpeter (1942, pp. 167, 172-3) asked: 'Can socialism work?' Although he did not favour such a system, he echoed contemporary and widespread opinion with his immediate answer: 'Of course it can'. He further insisted that: 'There is nothing wrong with the pure theory of socialism.' Like others, Schumpeter accepted the Lange-Taylor model as a convincing demonstration of the feasibility of a socialist system. For him, Mises and Hayek were 'definitely wrong' (Schumpeter, 1954, p. 989 n.). Schumpeter influenced his student Paul Samuelson, who promulgated a similar assessment of the debate in his famous textbook (Samuelson, 1948).

economy. But the debate also addressed other problems with socialism, such as the lack of incentives and the totalitarian dangers in the concentration of economic power in the hands of the state. Often neglected were earlier economic arguments against socialism by Albert Schäffle (going back to the 1870s) and later ones by Michael Polanyi. The calculation debate label concentrates on one aspect of one argument, where in fact there were more issues, more debaters and more debates (Hodgson, 2019c).

18 It is a mistake to describe the models of Lange, Dickinson and others as "market socialism'. Their proposals involved simulated market arrangements where the state ended up fixing final prices. They did not involve devolved property rights that were meaningfully established and contractually exchanged. 
Any scientific community relies on trust in authority. It is impossible for every researcher to scrutinize every argument or debate. Consequently, when renowned figures such as Schumpeter and Samuelson claimed that Lange was right, most did not question the verdict. Dissenters to this opinion were dismissed or ignored.

D. Mario Nuti obtained a PhD from Cambridge and was a Fellow of King's College, Cambridge from 1965 to 1979. In 1972, Alec Nove - an expert on the Soviet economy - and Nuti published a reader on socialist economics. It included classic articles by Mises and Lange that were part of the debate. Yet the editors assumed in their introduction that Lange had 'found an answer' to Mises and other critics of socialism (Nove and Nuti, 1972, p. 12). ${ }^{19}$

Years later, Elizabeth Durbin (1985, p. 233) - the daughter of one of the participants in the debate - still believed that Lange's work was 'the authoritative answer' to Mises and Hayek, and that practical socialism was possible with central planners using Lange's simulated market mechanism. Even later, the influential US economists Andrei Shleifer and Robert Vishny (1994, p. 166) - who themselves were not socialists wrote in a prestigious American Economic Association journal that the objections of Mises and Hayek to socialism 'were effectively rebutted by Lange'.

The notion that Lange and others had triumphed in the socialist calculation debate did not meet an effective challenge until the 1980s. Then the tide of interpretative opinion over the debate began to turn. The swell was increased by the growing political influence of Chicago-style, free-market ideas and by the rising academic stature of Hayek and other Austrian economists. All this destroyed the former authoritative consensus in favour of Lange.

But the questionable political context does not invalidate the content of the argument. Among others, Karen Vaughn (1980), Peter Murrell (1983) and Donald Lavoie (1985) produced scholarly re-evaluations of the socialist calculation debate. ${ }^{20}$ The overwhelming and persuasive conclusions of these studies were that Lange and others had failed to answer adequately the criticisms of Mises and Hayek. Lange and others had not provided a satisfactory outline of a workable and dynamic socialist

\footnotetext{
19 Nove later expounded the view that extensive markets were necessary in any feasible socialism (Nove, 1980, 1983).

20 See also Steele (1992), Boettke (2000, 2001) and Hodgson (1999a, 2018, 2019c). The broad validity of the Austrian critique of central planning is accepted by some authors who are sympathetic to socialism (Burczak, 2006).
} 
system and they had not appreciated the chronic inadequacies of the Walrasian general equilibrium approach.

But these developments were too late to change Cantabrigian heterodoxy. Dobb and Robinson did not question the feasibility of socialism any further, because like others they wrongly believed that Lange and others had demolished the Austrian case.

Robinson (1964b, p. 410) once approved a remark by Robert Solow that 'the notion of factor allocation in conditions of perfect competition makes sense in a normative theory of a planned economy rather than a descriptive theory of a capitalist economy, and that the notion of the marginal productivity of investment makes sense in the context of socialist planning.' This remark questionably assumes that marginal products are meaningful and measurable in a socialist planned economy, and can serve as guidelines for socialist managers, as Lange and others had presumed. Blaug (1993, p. 1571) wrote with appropriate derision:

The Lange idea of managers following marginal cost-pricing rules because they are instructed to do so, while the central planning board continually alters the prices of both producer and consumer goods so as to reduce their excess demands to zero, is so administratively naive as to be positively laughable. Only those drunk on perfectly competitive, static equilibrium theory could have swallowed such nonsense.

The omission of the socialist calculation debate endured in key Cambridge texts. The long-awaited but ill-fated textbook by Robinson and John Eatwell (1973) has chapters on socialist states and socialist planning, but there is no mention on its pages of the socialist calculation debate. Related epistemic problems of knowledge and uncertainty are given no more than brief attention, despite the declared devotion to the legacy of Keynes. ${ }^{21}$

The New Palgrave Dictionary of Economics, edited by Eatwell with Murray Milgate and Peter Newman, was published in 1987. It has 4100 pages and four volumes. Blaug (1990, p. 236) commented:

Despite entries on socialism, socialist economics and market socialism, and biographical entries on Oskar Lange and Ludwig von Mises, the Socialist Calculation Debate, so crucial in the revival of general equilibrium theory and

21 On the fate of the Robinson-Eatwell textbook see King and Millmow (2003) and Harcourt and Kerr (2009, ch. 10). 
the rise of modern welfare economics in the 1930s, is nowhere discussed at length in the New Palgrave. ${ }^{22}$

The socialist calculation debate was important not simply because it questioned the viability of socialist planning. Lange and others had used Walrasian general equilibrium theory to defend socialism. In this context, Hayek (1948) developed a major critique of general equilibrium theory, which highlighted the nature and role of knowledge. Robinson and Eatwell were also strong critics of general equilibrium theory, but they did not mention the use of that theory in defending the viability of socialism. On the contrary, they wrote: 'For the neoclassicals laissez-faire became a dogma, and the benefits of free trade an article of faith.' They saw 'equilibrium theory' as 'an exposition of the presumption in favour of laissez-faire' (Robinson and Eatwell, 1973, pp. 47, 336). ${ }^{23}$

Even today, the socialist calculation debate is seldom taught on undergraduate or postgraduate courses in economics. It does not readily fit into formal models. When students - now alas rarely - get taught some history of economic thought, it is often excluded from there too. ${ }^{24}$

Yet it is arguably the most important debate in economics in the twentieth century. Furthermore, for Cambridge left economists, the battle between socialism and capitalism was among their foremost considerations. Yet they quickly passed over this vital controversy on the feasibility of their socialist goals. The Austrian critique was unanswered and generally assumed to be wrong.

The core analytic concerns of this debate are extremely important. These include the roles of information and knowledge in the economy, and the importance and nature of incentives. Orthodoxy gives much

22 In his forensic review of the New Palgrave, Blaug (1990, pp. 211-12, 231) wrote that 'there is a large number of extremely sympathetic and even adulatory expositions of Marxian economics but not one single critical account of Marx's ideas (with one possible exception ...). Similarly, there are some 50 expositions of Sraffian economics under various headings but only two entries ... which even begin to entertain the possibility that Sraffa's words may not represent the alpha and omega of economics. ... Marx and Sraffa are quoted ... much more frequently than Adam Smith, Alfred Marshall, Leon Walras, Maynard Keynes, Kenneth Arrow, Milton Friedman, Paul Samuelson or whoever you care to name.'

23 Similar claims that 'orthodox economics is a de facto defense of capitalism' (Canterbery, 2010, p. 99) were promoted by US radical economists Edwards et al. (1972) and others.

24 Alessandro Roncaglia researched in Cambridge in 1971-73 under the supervision of Sraffa. Roncaglia's (2005, p. 318 n.) prize-winning History of Economic Thought mentions the debate between Mises, Hayek and Lange over socialism in one footnote, where it is written that Lange 'answered' the arguments of Mises and Hayek. No credence is given to the possibility that his answers were inadequate. 
attention to incentives, even if its answers can be faulted. By contrast, Cambridge heterodoxy, and the heterodox economics it has inspired, have given less attention to the role of incentives and to their psychological grounding. Problems of dispersed information and tacit knowledge are often overlooked. Cambridge heterodoxy was forged in these terms.

Lange and others had used neoclassical general equilibrium models and assumed away key information problems including dispersed and tacit knowledge. This should have alerted vigilant Cambridge critics of neoclassical economics that something might be wrong in the defence of socialism by Lange and others. Cantabrigian heterodoxy failed to pick up this scent, partly because their socialist ideology prevailed over any spirit of critical investigation into this discrepancy.

Cantabrigian heterodoxy made much of the claim that they were socialists, yet the socialist calculation debate raised questions of the feasibility of comprehensive central planning under socialism. Furthermore, attention to the debate would have overturned the frequent - but false - heterodox claim that neoclassical economics necessarily supports a market economy. The neglect of the debate betrayed major problems within Cantabrigian heterodoxy itself.

Of course, markets have their problems. As heterodox economists are aware, there are problems with externalities, social costs and the social and ecological limits to growth (Pigou, 1920; Kapp, 1950; Hirsch, 1977). But planning has problems as well. Saying (rightly) that markets have problems does not remove the difficulties from planning.

\section{FACULTY BATTLES}

The Faculty of Economics and Politics at the University of Cambridge was a battleground, where matters of institutional control, economic doctrine and political affiliation were fiercely contested. Johnson reported that to get elected to the Faculty Board required, among other things, 'strong attachment to the left or the right wing of the Department. The Faculty Board was a strongly political body, in the sense of both academic and party politics.' He also noted 'the bitterness of the controversies' (Johnson and Johnson, 1978, pp. 91, 134). This polarization discouraged the occupation of moderate or centre-ground positions. Political affiliation sometimes overshadowed academic merit.

Robert Neild obtained an economics degree at Cambridge in 1947. He returned to Cambridge in 1956 as a Teaching Fellow at Trinity College. In addition to lectures, he had to do twelve hours of college supervising (tutoring) of individual students each week, one or two at a time. 'The 
other dark aspect of life was the political goings-on in the economics faculty' (Neild, 2012, p. 73). Neild reported later in an interview: 'I found the faculty awful, it was so political and savage and full of prima donnas' (Hodgson et al., 2018, p. 769). Richard Kahn once expressed disappointment when Neild voted in the Faculty elections for a mixed ticket, rather than wholly for the left list. Neild (2012, pp. 73-4) felt he 'was caught by a mafia and had been subjected to bullying by its capo. My distaste for the ways of the faculty was one reason why I left Cambridge after two years. ... I was interested in doing research into how the economy worked, for which I had little time while committed to so much teaching' ${ }^{25}$

Amartya Sen came to Cambridge as a student of economics in 1953. In 1958 he received a four-year Prize Fellowship from Trinity College. Sen (1999) recollected 'intense fights between different schools of thought' where 'the political lines were, in general, very firmly - and rather bizarrely - drawn. In an obvious sense, the Keynesians were to the "left" of the neo-classicists, but this was very much in the spirit of "this far but no further"'. Sen recalled an incident where Dobb had defeated Kaldor in an election to the Faculty Board, which suggests that Kaldor was not on the left ticket at that time. Sen (1999) continued:

Kaldor was, in fact, much the most tolerant of the neo-Keynesians at Cambridge. If Richard Kahn was in general the most bellicose, the stern reproach that I received often for not being quite true to the new orthodoxy of neo-Keynesianism came mostly from my thesis supervisor - the totally brilliant but vigorously intolerant Joan Robinson.

In the early 1930s, as a research student at the London School of Economics, Kaldor had been influenced by Hayek. But he became disenchanted with Hayek's monetary theory and became a Keynesian. Kaldor was appointed a Fellow of King's College and a university lecturer in economics in 1949. He was a practical social-democrat rather than a supporter of full-blooded socialism. He was also a friend of Hugh Gaitskell, who was leader of the Labour Party from 1955 to 1963, and the champion of its 'right' or 'revisionist' wing. Kaldor became an

25 Neild returned to Cambridge as a full professor of economics in 1971. He took advantage of a relatively generous retirement package in 1984. In retirement he worked on institutional and evolutionary economics (Neild, 1995, 2002). Hitherto, institutional and evolutionary economics had been largely neglected in Cambridge. But Neild's work in this area was developed largely in the isolation of Trinity College, and it failed to cite many related or complementary publications elsewhere. Consequently, it passed relatively unnoticed within the rising global communities of institutional and evolutionary economists (Hodgson et al., 2018). 
advisor to the newly-elected Labour Government under Harold Wilson in 1964 (Targetti, 1992; Thirlwall, 1987). Although Kaldor had published some major theoretical papers in his early years, his economics developed in a practical and empirical direction to an extent greater than the norm for Cambridge left economics. Kaldor 'cared little about the measurement of capital and its aggregation, or about the production function, obsessions for Joan Robinson' (Bliss, 2010, p. 635). ${ }^{26}$

Luigi Pasinetti $(1974,1981)$ was at Cambridge from 1960 to 1976, and he tried to combine Kaldorian and Sraffian approaches. Pasinetti was denied a chair in Cambridge and returned to his native Italy in 1976.

Christopher Bliss was a lecturer at Cambridge from 1966 to 1971, and he reflected on the faculty fights: 'Kahn had an outstanding mind, much of it eventually wasted when he devoted his energies to devious academic politicking. ... Robinson had a bad habit of bullying anyone who did not accept her opinions' (Bliss, 2010, p. 633). But, if true, she had no monopoly on such behaviour: it also came from the other side of the Cambridge battle-lines.

Bliss (2010, p. 632) attributed the culture of animosity in Cambridge economics to the 'tradition of self-righteous intolerance that flowed from Keynes'. But it is difficult to believe that Keynes was largely responsible for more than half a century of vicious antagonism. Other factors were the politicization of its economics from the 1930s onwards, heightened by the Cold War, and later by the revolutionary 1960s. Some Cambridge economists saw themselves as fighting a war against the West. Such heightened ends encouraged belligerent means.

Cambridge economists were divided on matters of both analytical approach and political standpoint. It was not a simple division between political left and right, but it was made simpler by (quite wrongly) the frequent assumption that proponents of neoclassical economics must necessarily be right-wing apologists for a market economy.

Cambridge left economics was developed when the world was divided between capitalism and socialism. In the 1930s, politics had been pulled apart by communism on the left and fascism on the right: less credence had been given to the centre ground. Liberals like Keynes were the exceptions. Socialism dominated progressive thought in this era. As Michael Polanyi (1945, p. 142) put it: 'as the century advanced the socialist movement came near to absorbing all that was progressive,

26 Some major empirical contributions were partly stimulated by Kaldor's (1966, 1975b, 1978) attempts to establish 'stylized facts' about capitalist dynamics (Rowthorn, 1975a, 1975b, 1979; Rowthorn and Wells, 1987). The empirical work of Singh (1975) should also be recognized, among others. 
humane and intelligent in the mind of the age.' The development of the middle ground was stunted. Apart from Kaldor and a few others, Cambridge heterodoxy offered little defence for any economy involving markets or a private sector. A pragmatic economics for a socialdemocratic mixed economy was slow to develop. It was overshadowed by abstract theory of little empirical relevance and an impractical and ill-informed socialist idealism.

\section{CAMBRIDGE COLONIES WITHOUT THE CAMBRIDGE CITADEL}

The victory of the Cambridge UK side in the capital theory debates in the late 1960s boosted the confidence of Cantabrigian heterodoxy. Robinson visited the US several times in the 1960s. Cantabrigian 'left-wing economics' (as some have described it) became international.

The Cambridge-inspired network involved prominent American postKeynesians including Paul Davidson, Alfred Eichner, Jan Kregel, Edward Nell and Sidney Weintraub. Nell was introduced to Cambridge criticisms of neoclassical economics while at Oxford in the 1950s. Davidson corresponded with Robinson in the 1960s and he took study leave in Cambridge from 1970 to 1971. Influenced by Davidson, Kregel went to Cambridge for the 1968-69 academic year. Eichner worked on the theory and empirics of oligopoly and mark-up pricing. He contacted Robinson in 1969. Weintraub also engaged with Cambridge ideas (Lee, 2009, ch. 5).

In 1971 Robinson met Eichner and Luigi Pasinetti at Columbia University in New York. They agreed on further initiatives, including a meeting within the large forum of the Allied Social Science Association (which houses the American Economic Association and several other economics societies) in New Orleans in December 1971. Among the 17 attendees were Davidson, Eichner, Kregel, Nell and Hyman Minsky. These efforts, at which Robinson was at the centre, launched postKeynesian economics in North America (Lee, 2009, ch. 5).

The Journal of Post Keynesian Economics was established in 1978, under the joint editorship of Davidson and Weintraub. They made links with other US-based heterodox groups, principally the (original) institutionalist Association for Evolutionary Economics and their Journal of Economic Issues, the Marxist-inspired Union for Radical Political Economics and their Review of Radical Political Economics, and with the 
Association for Social Economics and their Review of Social Economy. All these were pluralist, left-leaning heterodox networks (Lee, 2009, ch. 5).

But the days of ascendant heterodoxy in Cambridge were numbered. Its defeat resulted from external and internal forces. By 1975, Kaldor, Robinson and Sraffa had all retired from their positions at Cambridge. Their departure weakened an already-fragmented Cambridge heterodoxy.

The expansion of the UK university system was another factor. An increase in the number of UK universities followed the Robbins Report of 1963. A second wave of expansion began in the late 1980s. Overall participation in higher education in the relevant age group more than doubled from 3.4 per cent in 1950, to 8.4 per cent in 1970, and more than doubled again to 19.3 per cent in 1990 (National Committee of Inquiry into Higher Education, 1997). It has more than doubled again, to over 40 per cent, in subsequent years. The expansion of the UK university sector put pressure on the ancient Oxbridge universities. They could no longer automatically assume pre-eminence.

This substantial expansion came too late to prevent a decisive shift of intellectual dominance in economics from Britain to the US. The increase in the number of UK universities, plus the conclusive shift of international leadership in economics to the US, put Cambridge economics under pressure to adapt.

The Economic Journal was the most prestigious journal in this discipline in the UK. It had been located at Cambridge since its foundation in 1891. From 1912 to 1944 it was edited by Keynes. But with its membership swelled by economists from the expanding UK university sector, the Royal Economic Society decided to move the journal away from Cambridge. This was accomplished in 1976. This move was a major stimulus behind the launch in 1977 of the heterodox and left-leaning Cambridge Journal of Economics.

While he was an undergraduate at Cambridge, Samuel Coldicutt (2010) conducted interviews with several of the key participants in the climactic Faculty battles of the 1980s. The Cambridge left were generally better organized. To mobilize their potential support on the Faculty Board, they would organize telephone canvasses of voters. By contrast, the orthodox faculty members often did not agree on a single candidate and hence their vote was split. Consequently, the left candidates for key elections - most importantly for the Appointments Committee - were often successful.

Robin Matthews was regarded as one of the more orthodox economists in Cambridge. At the time he was on the University Council of the Senate with influence over the General Board of the Faculties. He 
proposed that the single transferable vote system (STV) be used in all elections throughout the university. Under STV, candidates are ranked in order of preference, and those with weaker support are eliminated one by one, each time transferring subsequent preferences to the remaining candidates. So even if the orthodox or 'right' vote were split between multiple candidates, STV meant that preferences could transfer to the remaining 'right' contenders. Matthews admitted in his interview with Coldicutt (2010, pp. 30-31) that while the introduction of STV was a rule that applied to the university as a whole, for him the undermining of heterodox control in the Faculty of Economics and Politics 'was the whole point' of the change. Although according to Harcourt (2017), Matthews expressed some regrets about the outcome in the Faculty.

As a result of this university-wide change of rules, the heterodox majority on the Faculty Board dwindled in 1987 and had disappeared for good by 1988. Another factor was the introduction of a national system for assessing university research, then known as the Research Assessment Exercise (RAE). The first nationwide RAE was held in 1986. With the second, held in 1989, the RAE became the primary means for determining public allocations of research funds to UK universities. The nationwide RAE panels charged with assessing university research in economics were dominated by orthodox economists from the beginning. Even if heterodoxy had held onto power in Cambridge, it would have faced the severe problem of orthodox dominance of the nationwide RAE. ${ }^{27}$

Under orthodox control, the Faculty made changes to the curricula and swelled their ranks with new orthodox appointments. While previously the MPhil exams at Cambridge were disposed towards questions on the economics of Sraffa, Robinson and other heterodox dissenters, these 'traces of heterodoxy were absent from MPhil examinations after 1998' (Coldicutt, 2010, p. 16). But of course, Keynesian approaches were still discussed in the macroeconomics curriculum.

Once orthodoxy became a serious challenge to the heterodox economists in Cambridge, they were forced to debate on some issues that were prominent elsewhere but had been relatively neglected in their previous teaching or research. As Harcourt pointed out in an interview: 'it's hard to be a heterodox economist because not only do you have to develop heterodoxy but you have to keep up to date with orthodoxy - you have double the work to do and this has worked against the left' (Coldicutt, 2010, p. 47).

27 The RAE has since been re-named the Research Excellence Framework (REF). 
If it were not located in a prestigious faculty of a leading world university, it is doubtful that heterodox economics would have survived in Cambridge until the 1980s. Status and prestige made it possible to choose its own agenda and overlook some important ideas from elsewhere. Heterodox economists in other universities were less fortunate. But as the academic world moved on, research in economics became more global, and Cambridge was forced more and more to compete with leading universities elsewhere and abroad. This too was a factor in the termination of heterodox control.

\section{CONCLUSION: THE EFFECTS OF ISOLATION AND EXCESSIVE POLITICIZATION}

As academia expanded and globalized, it was perhaps inevitable that American-style orthodox economics would triumph in Cambridge. A relevant question is whether it would have been possible for Cambridge heterodoxy to adopt a strategy that could have led to a more pluralist outcome, where a significant heterodox contingent endured alongside a substantial orthodox block. Among other things, this would have allowed Cambridge economics to recruit students who were attracted by its heterodox tradition of thought, while giving them a fuller exposure to what was happening within orthodoxy as well.

A number of factors worked against a pluralist settlement of this kind. Some of the orthodox economists were intolerant of heterodox dissent, and this was a serious problem. But taking such intolerance as given, what could heterodoxy have done to improve the chances and extent of its survival?

Greater attention to microeconomics would have helped. But the leading Cambridge heterodox economists did little work on market mechanisms (except their major contributions in imperfect competition and pricing theory), or on public goods and externalities, or on alternatives to the utility-maximizing model of individual behaviour. This large microeconomic territory was mostly conceded to orthodoxy from the outset.

The heavy politicization of economic rhetoric by Cambridge heterodoxy did not help either. There was little if any justification for labelling heterodoxy as left and orthodoxy as right. It needlessly antagonized the orthodox wing. In an interview, Matthews complained that he had been labelled as right: 'I always objected to that designation because I never regarded myself as particularly right-wing - quite the contrary, I was a 
man of the left' (Coldicutt, 2010, p. 21). The false description of social democrat Hahn as right has already been noted above.

As another example, James Meade was a professor at Cambridge from 1957 to 1967. He then became a senior research fellow of Christ's College - a post he held until 1974. He became a Nobel Laureate in 1977. He was a Keynesian in macroeconomics while embracing neoclassical microeconomics. He was a strong exponent of worker cooperatives and an advocate of a mixed, market economy. Embracing neoclassical theory and a mixed economy did not go down well with many on the Cambridge left.

Johnson observed how economics theory had been overly embroiled with political ideology in Cambridge: 'Keynesian economics was not a theoretical advance to be built on for scientific progress and improved social policy. It was only a tool for furthering left-wing politics at the level of intellectual debate.' (Johnson and Johnson, 1978, p. 150).

Heightened political polarization pushed people to the extremes. Those with nuanced or intermediate positions became casualties. Johnson witnessed in Cambridge 'the suppression of the free spirit of scientific enquiry by the use or threat of a witch-hunt'. He continued:

An economics profession in which people have to think 'before I dare to say what I think, I have to be sure that what I say will not damn me as hopelessly orthodox' is not one likely to discover new and important scientific truths. This baneful influence of concern about orthodoxy or heterodoxy as the hallmark of 'bad' or 'good' economics is vastly reinforced by the identification of Keynesian economics in Britain with left-wing or at least Labour party politics, and the politicization of economics that it has entailed. (Johnson and Johnson, 1978, p. 215).

Each side in the Cambridge battles bathed in the confirmation biases of like-minded thinkers. Groupthink encouraged searches for evidence to confirm a view, rather than to challenge it. Whole areas of research, which might have questioned each side's orthodoxy, were neglected. The value of political viewpoint diversity in the academy was under-unappreciated.

Any movement bears hallmarks from the context in which it was forged. As post-Keynesian and heterodox economics spread from Cambridge, some of their formative marks remained visible. Many of the Cambridge heterodox traits are found in its colonial outposts. We may summarize some of the important features of the strand of Cantabrigian thinking that spread from Cambridge from the 1970s, particularly under the leadership of Robinson: 
1. Keynes and Marx were the main icons of Cantabrigian heterodoxy. Kalecki was a crucial additional figure who bridged the two, and Sraffa was important in his own right. Adopted versions of Keynesianism stressed state intervention, but had less to do with his liberalism and his defence of capitalism.

2. Generally, there was greater attention to macroeconomics than microeconomics. Among the few microeconomic topics that were explored were alternatives to marginalist pricing theory, particularly administered or mark-up pricing.

3. Among the neglected microeconomic issues were psychological theories of motivation that do not entail utility-maximization (such as Simon's version of behaviouralism). Also overlooked were the nature and role of property rights and other key institutions, in framing activity and providing incentives. The importance of knowledge in production and markets (as stressed in different ways by Marshall, Veblen and Hayek) was inadequately appreciated. Instead there was a widespread focus on physical coefficients in production processes.

4. Neoclassical theory was sometimes identified as being intrinsically pro-market, despite the strong socialist views of pioneering neoclassical theorists such as Arrow, Lange and Lerner.

5. The economic and political feasibility of democratic socialism was often taken for granted. Debates within economics about the viability of socialism were either ignored, or theoretical arguments questioning the feasibility of socialism were briefly dismissed. Despite heterodox opposition to neoclassical theory, the use of neoclassical general equilibrium models by defenders of socialism was overlooked.

6. Just as Marshall and Keynes were sceptical of the value of formal models (Hodgson, 2012, 2013d), Cambridge heterodoxy made less use of mathematical models than orthodox economists. But before the work of Tony Lawson (1997), the Cambridge arguments for the limitation of mathematics were unclear.

These six features were also prominent, albeit with exceptions and variations, in the outposts of heterodoxy that were established in North America, Europe and elsewhere, under the influence of Robinson, Sraffa and other leading Cambridge scholars. As demonstrated in the following chapter, and despite its internal heterogeneity and its failure to define itself clearly, heterodoxy still bears the marks of its Cambridge origins. But thrust into the world beyond Cambridge, it had magnified problems in maintaining its status and identity. 